\title{
Enhanced 11ß-hydroxysteroid dehydrogenase type 1 activity in stress adaptation in the guinea pig
}

\author{
M Quinkler, H Troeger, E Eigendorff, C Maser-Gluth², A Stiglic ${ }^{1}$, \\ W Oelkers, V Bähr and S Diederich
}

\author{
Department of Endocrinology, Klinikum Benjamin Franklin, Freie Universität Berlin, Berlin, Germany \\ ${ }^{1}$ Research Facility for Experimental Medicine, Klinikum Benjamin Franklin, Freie Universität Berlin, Berlin, Germany \\ ${ }^{2}$ Department of Pharmacology, Ruprecht-Karls-Universität Heidelberg, Heidelberg, Germany \\ (Requests for offprints should be addressed to M Quinkler who is now at Division of Medical Sciences, Department of Medicine, Queen Elizabeth Hospital, \\ University of Birmingham, Edgbaston, Birmingham B15 2TH, UK; Email: M.O.Quinkler@bham.ac.uk) \\ (M Quinkler and $\mathrm{H}$ Troeger contributed equally to this work)
}

\begin{abstract}
The 11ß-hydroxysteroid dehydrogenases (11ß-HSDs) convert cortisol to its inactive metabolite cortisone and

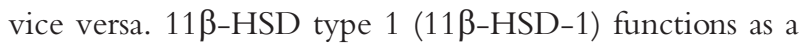
reductase in vivo, regulating intracellular cortisol levels and its access to the glucocorticoid receptor. In contrast, $11 \beta-H S D-2$ only mediates oxidation of natural glucocorticoids, and protects the mineralocorticoid receptor from high cortisol concentrations. We investigated the in vivo and in vitro effects of $\mathrm{ACTH}$ on the recently characterized $11 \beta-H S D$ s in guinea pig liver and kidney.

Tissue slices of untreated guinea pigs were incubated with ${ }^{3} \mathrm{H}$-labelled cortisol or cortisone and $\mathrm{ACTH}_{1-24}$ $\left(10^{-10}\right.$ and $\left.10^{-9} \mathrm{~mol} / \mathrm{l}\right)$. The $11 \beta-H S D$ activities in liver and kidney slices were not influenced by in vitro incubation with $\mathrm{ACTH}_{1-24}$.

In addition, guinea pigs were treated with $\mathrm{ACTH}_{1-24}$ or saline injections s.c. for 3 days. Liver and kidney tissue
\end{abstract}

slices of these animals were incubated with ${ }^{3} \mathrm{H}$-labelled cortisol or cortisone. In vivo ACTH treatment significantly increased reductase and decreased oxidase activity in liver and kidney. Furthermore, $11 \beta-$ HSD-1 activity assessed by measurement of the urinary ratio of (tetrahydrocortisol $(\mathrm{THF})+5 \alpha \mathrm{THF}) /($ tetrahydrocortisone) was significantly increased after ACTH treatment compared with the control group. Plasma levels of cortisol, cortisone, progesterone, 17-hydroxyprogesterone and androstenedione increased significantly following in vivo ACTH treatment.

The enhanced reductase activity of the hepatic and renal $11 \beta-H S D-1$ is apparently caused by cortisol or other ACTH-dependent steroids rather than by ACTH itself. This may be an important fine regulation of the glucocorticoid tonus for stress adaptation in every organ, e.g. enhanced gluconeogenesis in liver.

Journal of Endocrinology (2003) 176, 185-192

\section{Introduction}

The $11 \beta$-hydroxysteroid dehydrogenases (11 $\beta$-HSDs) convert 11-hydroxysteroids like cortisol and corticosterone to their inactive metabolites cortisone and 11dehydrocorticosterone and vice versa. Two different isoenzymes of $11 \beta-H S D$ have been cloned in the human (Tannin et al. 1991, Albiston et al. 1994) and several other animal species. The $\mathrm{NAD}^{+} /(\mathrm{H})$-dependent $11 \beta-\mathrm{HSD}$ type $2(11 \beta-H S D-2)$ enzyme is found in the placenta and in cells expressing the mineralocorticoid (MC) receptor (Albiston et al. 1994, Stewart 1996, Stewart \& Krozowski 1999, Quinkler et al. 2001). With the endogenous glucocorticoids (GCs) cortisol and corticosterone as substrates, $11 \beta-H S D-2$ acts exclusively as a dehydrogenase, whereas with $9 \alpha$-fluorinated steroids as substrates it is mainly a reductase (Oelkers et al. 1994, Diederich et al. 1997, Li et al. 1997). Further characteristics of $11 \beta-H S D-2$ are the strong end-product inhibition by 11-dehydro-GCs (Rusvai \& Náray-Fejes-Tóth 1993) and the ability to oxidize dexamethasone (Best et al. 1997, Li et al. 1997). The main function of $11 \beta-H S D-2$ is the protection of the unselective MC receptor, which has similar affinity to cortisol and aldosterone (Arriza et al. 1987). This isoenzyme converts large amounts of cortisol to cortisone, thus allowing the lower concentrated aldosterone to bind to the MC receptor (Edwards et al. 1988, Funder et al. 1988, Stewart 1996, Stewart \& Krozowski 1999, Quinkler et al. 2001).

The $\mathrm{NADP}^{+} / \mathrm{H}$-dependent $11 \beta-\mathrm{HSD}$ type $1(11 \beta-$ HSD-1) enzyme functions in vitro as a bidirectional oxidoreductase and is expressed ubiquitously. In vivo, the hepatic $11 \beta-H S D-1$ acts mainly as a reductase and activates inactive cortisone to cortisol (Jamieson et al. 1995, 2000, Voice et al. 1996). 11ß-HSD-1 of the guinea pig has recently been cloned and was present in all tissues 
examined, with highest levels in liver, kidney and the adrenal gland (Pu \& Yang 2000).

Whereas the function of $11 \beta-H S D-2$ is widely accepted, the function of $11 \beta-\mathrm{HSD}-1$ is not yet well understood. It is believed that $11 \beta-H S D-1$ modulates intracellular active GC concentration and occupancy of the GC receptor. In the fetal lung, the activation of cortisone to cortisol by $11 \beta-H S D-1$ is essential for the induction of surfactant synthesis (Hundertmark et al. 1995), in the ovary for modulation of follicular maturation during the follicular phase (Michael \& Cooke 1994, Tetsuka et al. 1997), and in adipose tissue for differentiation of adipocytes (Tomlinson et al. 2001, Stewart \& Tomlinson 2002). In the liver, $11 \beta-H S D-1$ plays a crucial role in GC-mediated effects such as gluconeogenesis, glycolysis and insulin sensitivity (Voice et al. 1996, Kotelevtsev et al. 1997), and it is probably involved in detoxification of nitrosamines (Maser et al. 1996).

Recently, we and others have suggested that the increased ratio of cortisol to cortisone in plasma and urine during adrenocorticotrophin $(\mathrm{ACTH})$ infusion in man (Eisenschmid et al. 1987, Walker et al. 1992) is not caused by a direct inhibitory effect of ACTH (Diederich et al. 1996), but is due to an overload of $11 \beta-H S D-2$ substrates such as cortisol and corticosterone with subsequent $11 \beta$ HSD-2 inhibition (Ulick et al. 1992).

Stress activates the hypothalamo-pituitary-adrenal axis and the sympathetic nervous system. During stress, ACTH, corticosteroid and catecholamine concentrations are high, as are other stress hormones. The plasma corticosteroid levels are the most striking changes during stress, and are regarded as a sensitive index of stress. Corticosteroid levels are regulated by the 11 $\beta-\mathrm{HSD}$ enzymes, but it is not known how the latter respond to stress situations. We have recently characterized the $11 \beta$ HSD isoenzymes in the guinea pig liver and kidney (Quinkler et al. 1997). In this paper we describe the effects of in vivo ACTH administration for 3 days on the $11 \beta$-HSDs and the in vitro effects of ACTH on these enzymes in guinea pig liver and kidney tissue slices.

\section{Materials and Methods}

\section{Chemicals and solutions}

Cortisol and cortisone were obtained from Sigma Chemical Co. (St Louis, MO, USA), [1,2,6,7- $\left.{ }^{3} \mathrm{H}(\mathrm{n})\right]-$ cortisol (specific activity: $70 \cdot 0 \mathrm{Ci} / \mathrm{mmol}$ ) from DuPont de Nemours GmbH (Bad Homburg, Germany), and $\left[1,2(\mathrm{n})-{ }^{3} \mathrm{H}\right]$-cortisone (specific activity: $41 \mathrm{Ci} / \mathrm{mmol}$ ) from Amersham International plc (Amersham, Bucks, UK). Both tritiated steroids were purified by high performance liquid chromatography (HPLC) prior to use. The steroids were dissolved in methanol and kept at $-20^{\circ} \mathrm{C}$. Synacthen $\left(\mathrm{ACTH}_{1-24}\right)$ was purchased from Ciba-Geigy $\mathrm{GmbH}$ (Wehr, Germany), ketamine from Sanofi Ceva (Düsseldorf, Germany) and xylazine (Rompun) from
Bayer AG (Leverkusen, Germany). Acetone, ethanol, n-hexane and 2-propanol (all LiChrosolv quality) were purchased from Merck GmbH (Darmstadt, Germany), methanol in LiChrosolv quality from $\mathrm{J} T$ Baker $\mathrm{BV}$ (Deventer, The Netherlands), Sep-Pak $\mathrm{C}_{18}$ cartridges from Waters Millipore $\mathrm{GmbH}$ (Eschborn, Germany) and radioactivity scintillant 'Instant Scint Gel Plus' from Packard Instruments BV (Groningen, The Netherlands).

\section{Animals}

Male Duncan-Hartley guinea pigs (weight $300 \mathrm{~g}$ ) were provided by Moellegard Breeding Centre (Schönwalde, Germany), and kept under standard conditions and on a control diet. The study was approved by the local ethics committee and is in agreement with UK legal requirements. The animals were randomly divided into two groups. One group $(n=6)$ was stimulated with $0.1 \mathrm{ml}$ depot $\mathrm{ACTH}_{1-24}(10 \mathrm{IU})$ by s.c. injection twice daily (at $0800 \mathrm{~h}$ and $1800 \mathrm{~h}$ ) for the last 3 days before they were killed. The other group $(n=6)$ received injections of $0.1 \mathrm{ml}$ saline $(0.9 \%)$ as a placebo at the same times. One hundred and fifty minutes after the last injection of $\mathrm{ACTH}_{1-24}$ or saline in the morning, the animals were anaesthesized with ketamine combined with xylazine by intramuscular injection. Blood samples were obtained by heart puncture, and plasma was stored at $-20{ }^{\circ} \mathrm{C}$ until analysis. The animals were killed, and the livers and kidneys quickly removed and kept in cold saline until the onset of incubation (maximum duration from death to onset of incubation was $70 \mathrm{~min}$ ). Urine was collected over $24 \mathrm{~h}$ on the day before the injections started and before the animals were killed. The urine samples were stored at $-20{ }^{\circ} \mathrm{C}$ until analysis. Plasma steroids were measured by HPLC or radioimmunoassay (RIA); tetrahydrocortisol (THF), $5 \alpha \mathrm{THF}$ and tetrahydrocortisone (THE) concentrations in 24-h urine samples were analyzed by RIA (Maser-Gluth et al. 2000). Guinea pig liver and kidney tissues were cut into $1 \mathrm{~mm}$ slices, and $70 \mathrm{mg}$ wet tissue was weighed out for each incubation well. The incubation volume of $1 \mathrm{ml}$ Krebs-Ringer-bicarbonate-glucose buffer contained $100 \mu \mathrm{l}\left[{ }^{3} \mathrm{H}\right]$-cortisol or $\left[{ }^{3} \mathrm{H}\right]$-cortisone $(100000$ c.p.m. $=10^{-9} \mathrm{~mol} / \mathrm{l}$ ) and unlabelled cortisol or cortisone $\left(10^{-7} \mathrm{~mol} / \mathrm{l}\right)$. The incubation time was $90 \mathrm{~min}$, and four independent incubations for each tissue and reaction direction were performed. Incubations of tissue slices were carried out in a shaking preheated $\left(37^{\circ} \mathrm{C}\right)$ steel chamber with a $95 \% \mathrm{O}_{2}$ and $5 \% \mathrm{CO}_{2}$ gas supply as described previously (Oelkers et al. 1994, Diederich et al. 1996).

The possibility of a direct effect of $\mathrm{ACTH}_{1-24}$ on renal or hepatic $11 \beta-\mathrm{HSD}$ of the guinea pig was tested by measuring the conversion of cortisol to cortisone and vice versa in the presence of two concentrations of $\mathrm{ACTH}_{1-24}$ $\left(10^{-10}\right.$ and $\left.10^{-9} \mathrm{~mol} / \mathrm{l}\right)$. The same amounts of tissue, radioactive tracer and unlabelled cortisol/cortisone were used as described above. For studies of enzyme kinetics we studied the renal and hepatic $11 \beta$-oxidation and 
-reduction in guinea pig tissues by measuring the conversion of $\left[{ }^{3} \mathrm{H}\right]$-cortisol $\left(100000\right.$ c.p.m. $\left.=10^{-9} \mathrm{~mol} / \mathrm{l}\right)$ to $\left[{ }^{3} \mathrm{H}\right]$-cortisone and vice versa in the presence of increasing concentrations of unlabelled cortisol or cortisone $\left(10^{-9}\right.$ to $\left.10^{-5} \mathrm{~mol} / \mathrm{l}\right)$. For each concentration, tissue and reaction direction, three independent incubations were performed (incubation time $90 \mathrm{~min}$ ).

\section{Analytical procedure}

The incubation was stopped by transferring the incubation set on ice and by removing the supernatant fluid. Precipitation of protein and cleaning of samples with Sep-Pak $\mathrm{C}_{18}$ cartridges and HPLC procedure with ${ }^{3} \mathrm{H}$ measurement were performed as described previously (Diederich et al. 1996). In the in vivo experiment steroids were extracted as mentioned above, but were spotted on a thin-layer chromatography plate that was developed in dichloromethane/methanol $(15: 1, \mathrm{v} / \mathrm{v})$. The bands containing cortisol and cortisone were identified by UV light of the unlabelled carriers, cut out, transferred into scintillation vials and analyzed in a beta-counter. The interconversion of 11-hydroxy- or 11-oxosteroids by tissue slices was expressed as percentage of the total steroid measured.

\section{Statistics}

Statistical calculations were done with an SPSS program from SPSS Inc. (Chicago, IL, USA). The Duncan multiple range and the Mann-Whitney rank sum tests as well as the independent $t$-test were used.

\section{Results}

Guinea pig in vivo experiment

The mean weight of guinea pigs of the ACTH subgroup was $305.5 \pm 11.3 \mathrm{~g}$ and that of the control group was $301.7 \pm 15.4 \mathrm{~g}$ before the experiment. The animals of each group gained weight significantly during the experiment, resulting in slightly heavier ACTH-treated animals $(377 \cdot 5 \pm 10 \cdot 4 \mathrm{~g})$ than control animals $(370 \cdot 5 \pm 20 \cdot 5 \mathrm{~g})$. There was no significant difference in weight between the ACTH-treated animals and the control animals.

Serum cortisol concentrations rose significantly from $525 \pm 194 \mathrm{nmol} / 1$ to $2679 \pm 640 \mathrm{nmol} / 1$ following ACTH treatment for 3 days. Plasma cortisone concentrations rose likewise from $55 \pm 18 \mathrm{nmol} / 1$ (control guinea pigs) to $336 \pm 62 \mathrm{nmol} / \mathrm{l}$ in ACTH-treated animals (Table 1). The serum cortisol/cortisone ratio was not altered significantly in ACTH-treated or control animals. Other steroids measured (progesterone, $17 \alpha-$ hydroxyprogesterone and androstenedione) increased significantly following in vivo ACTH treatment (Table 1). Plasma dehydroepiandrosterone sulphate (DHEA-S) concentrations were below the assay detection limit in control animals and slightly above the limit in ACTH-treated animals.
Table 1 Serum concentrations of different steroids in ACTH-treated and control guinea pigs. Values are means \pm S.D. ( $n=6$ in each group)

\begin{tabular}{|c|c|c|c|}
\hline & $\begin{array}{l}\text { Control } \\
\text { animals }\end{array}$ & $\begin{array}{l}\text { ACTH-treated } \\
\text { animals }\end{array}$ & $\begin{array}{l}\text { Control vs } \\
\text { ACTH } \\
\text { (t-test) }\end{array}$ \\
\hline \multicolumn{4}{|l|}{$\begin{array}{l}\text { Serum concentration } \\
(\mathrm{nmol} / \mathrm{l})\end{array}$} \\
\hline Cortisol & $525 \pm 194$ & $2679 \pm 640$ & $P<0.001$ \\
\hline Cortisone & $55 \pm 18$ & $336 \pm 62$ & $P<0.001$ \\
\hline Progesterone & $2 \cdot 7 \pm 0 \cdot 3$ & $10 \cdot 9 \pm 2 \cdot 1$ & $P<0.001$ \\
\hline $17 \alpha$-Hydroxyprogesterone & $0 \cdot 35 \pm 0 \cdot 15$ & $2 \cdot 32 \pm 0 \cdot 6$ & $P<0.001$ \\
\hline Androstenedione & $2 \cdot 3 \pm 0 \cdot 6$ & $10 \cdot 7 \pm 4 \cdot 7$ & $P<0.005$ \\
\hline DHEA-S & $<0.135$ & $0 \cdot 189 \pm 0 \cdot 014$ & $P<0.001$ \\
\hline
\end{tabular}

The urinary excretion of cortisol, cortisone, THF, $5 \alpha \mathrm{THF}$ and THE increased significantly under ACTH treatment (Table 2). Surprisingly the urinary cortisol/ cortisone ratio did not increase after ACTH treatment, whereas the urinary excretion of THF $+5 \alpha \mathrm{THF} / \mathrm{THE}$ showed a significant increase compared with the ratio before ACTH treatment and to the control group (Fig. 1). The urinary ratio $5 \alpha \mathrm{THF} / \mathrm{THF}$, representing the balance between $5 \alpha$-reductases and $5 \beta$-reductase activities, remained unchanged in control and ACTH-treated animals before and after treatment (Table 2).

\section{Guinea pig in vitro experiments}

Incubations with $\left[{ }^{3} \mathrm{H}\right]$-cortisol to $\left[{ }^{3} \mathrm{H}\right]$-cortisone and vice versa in the presence of increasing concentrations of unlabelled cortisol or cortisone $\left(10^{-9}\right.$ to $\left.10^{-5} \mathrm{~mol} / \mathrm{l}\right)$ in untreated guinea pig liver and kidney tissue slices showed typical enzyme kinetics with no substrate overload (data not shown).

Three days of in vivo ACTH treatment significantly increased the in vitro $11 \beta$-reductase activity in guinea pig liver $(50 \cdot 2 \%$ to $70 \cdot 3 \%)$ and kidney (39.6\% to $56 \cdot 8 \%)$ slices, whereas the $11 \beta$-oxidative activity was significantly decreased in both liver $(33.7 \%$ to $23.9 \%)$ and kidney $(33.9 \%$ to $28.6 \%)$ (Fig. 2). Due to the high conversion of substrate, and consequent difficulties in accurately measuring absolute conversion rates, the results observed may underestimate the difference between control and treatment groups

In vitro incubations of liver and kidney slices with increasing concentrations of $\mathrm{ACTH}_{1-24}$ had no significant effect on the interconversion of cortisol to cortisone (Table 3).

\section{Discussion}

The pituitary-adrenal system of the guinea pig (Cavia porcellus) is different from other rodents in several respects (Keightley \& Fuller 1996). The total plasma cortisol concentration in unstressed animals ranges between 260 
Table 2 Daily urinary excretion of free cortisol, cortisone, THF, $5 \alpha$ THF and THE in ACTH-treated and control guinea pigs. Values are means \pm S.D. ( $n=6$ in each group). Paired and unpaired $t$-tests were used

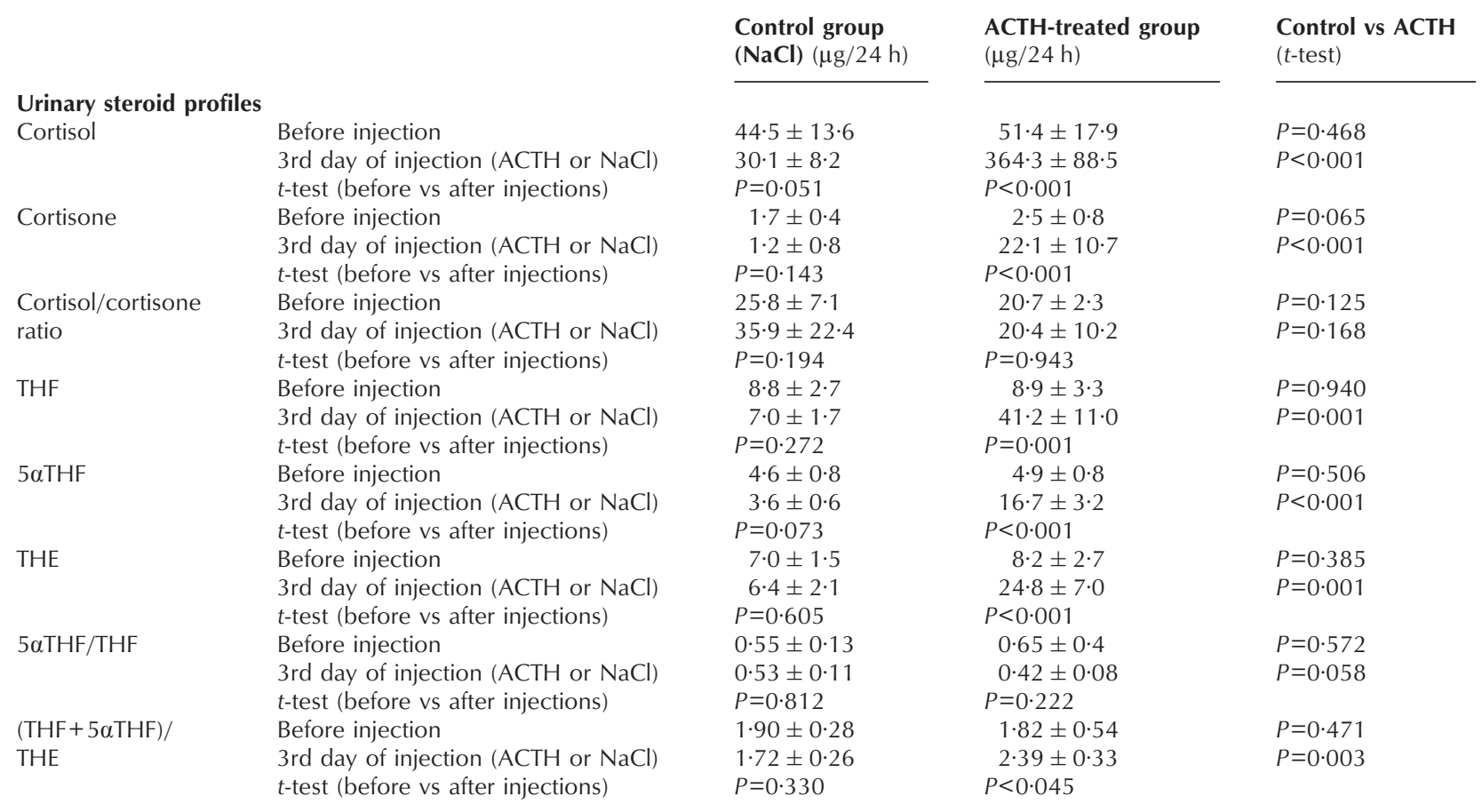

and $690 \mathrm{nmol} / 1$ (Fujieda et al. 1982, Fenske 1997), and free cortisol concentrations are at least three times higher than in humans (Fujieda et al. 1982). One reason for the

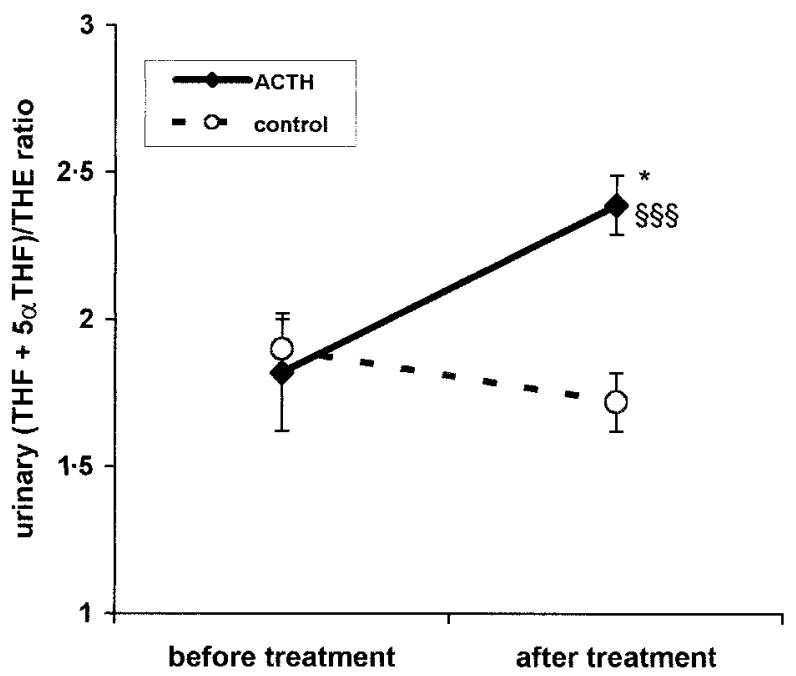

Figure 1 Urinary $(\mathrm{THF}+5 \alpha \mathrm{THF}) / \mathrm{THE}$ ratio of six $\mathrm{ACTH}$ - and $\mathrm{NaCl}$-treated guinea pigs. Values are means \pm S.E.M. Significant differences ( $\left.{ }^{\$} \$ P<0005\right)$ of the ratios after treatment in ACTH-treated versus the control group. Significant increase $\left({ }^{\star} P<0 \cdot 05\right)$ of the ratio in the $\mathrm{ACTH}$-treated group before versus after the injections. high circulating cortisol concentration may be the low affinity of the guinea pig GC receptor to cortisol (Hodgson \& Funder 1978, Kraft et al. 1979). In spite of high cortisol levels, the plasma ACTH concentration is comparable with that in other species (Martin et al. 1980), but the biological potency of guinea pig ACTH is increased (Keightley et al. 1991). The guinea pig MC receptor shows no differences from that of other species (Myles \& Funder 1994). We found that the guinea pig possesses a very strong $11 \beta-H S D-2$ activity in the kidney (Quinkler et al. 1997), which could be the major protecting mechanism for the MC receptor.

It is not known how $11 \beta-$ HSD activity and its reaction directions are influenced in chronic stress situations. Until now, only a few studies have addressed this topic. Nwe et al. (2000) investigated the 11ß-HSD-1 oxidative activity of testis and liver during stress in rats. They did not investigate reductase activity, which is the main function of $11 \beta$-HSD-1, and they used only homogenates. Tissue slices are preferrable to homogenates, because homogenization of tissue changes $11 \beta-H S D-1$ activity from reduction to oxidation (Oelkers et al. 1994, Bach et al. 1996). We therefore investigated the effect of 3 days of in vivo ACTH treatment on the interconversion of cortisol and cortisone in liver and kidney slices of the guinea pig.

Three days of ACTH treatment increased adrenal steroidogenesis. Besides increased cortisol and cortisone 

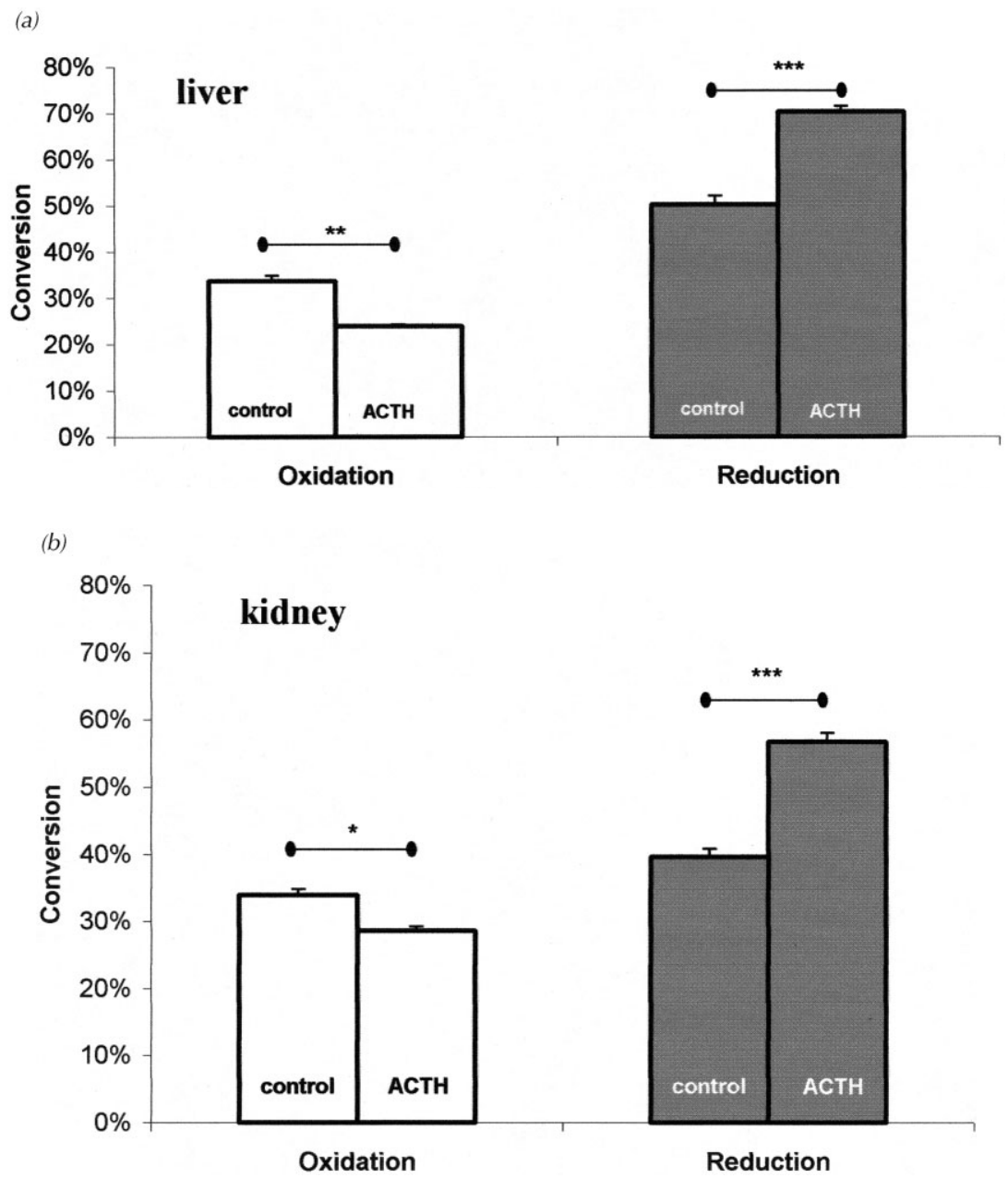

Figure 2 Conversion (\%) of $\left[{ }^{3} \mathrm{H}\right]$-cortisol and $\left[{ }^{3} \mathrm{H}\right]$-cortisone in guinea pig (a) liver tissue slices $(n=6)$ and $(b)$ kidney tissue slices $(n=6)$ of sham- and ACTH-treated animals; 100000 c.p.m. $\left[{ }^{3} \mathrm{H}\right]$-cortisol or $\left[{ }^{3} \mathrm{H}\right]$-cortisone and $10^{-7} \mathrm{~mol} / \mathrm{l}$ unlabelled cortisol or cortisone were used. The incubation time was $90 \mathrm{~min}$. Values are means \pm S.E.M. (a) ${ }^{* *} P<0 \cdot 005,{ }^{* *} P<0 \cdot 001$; (b) ${ }^{*} P<0 \cdot 05,{ }^{* *} P<0 \cdot 001$.

plasma concentrations (Table 1), we observed an increased production of progesterone, $17 \alpha$-hydroxyprogesterone and androstenedione suggesting an activated $17 \alpha$-hydroxylase and 17,20-lyase activity of P450c17 enzyme by ACTH treatment (Provencher et al. 1992). The DHEA-S plasma concentration was undetectable in untreated animals and was just measureable in ACTH-treated animals. The P450c17 enzyme of the guinea pig seems to prefer the progesterone-17 $\alpha$-hydroxyprogesterone-androstenedione pathway similar to rats (Shinzawa et al. 1985). This is in contrast to the human P450c17, which favours the pregnenolone-17 $\alpha$-hydroxypregnenolone-DHEA pathway.

In liver and kidney tissue slices, $11 \beta-H S D$ dehydrogenase activity decreased after in vivo ACTH treatment, whereas the $11 \beta-H S D$ reductase activity increased con- siderably compared with the control group. The equilibrium of the reaction was shifted towards the active 11-hydroxy side (Fig. 2). In guinea pig liver, 11 $\beta$-HSD1 mRNA expression and enzyme activity is predominant (Quinkler et al. 1997, Pu \& Yang 2000). Therefore, the increase of the reduction of cortisone is most likely due to an increase in 11 $\beta$-HSD-1 activity conferred by GCs (Jamieson et al. 1995, Liu et al. 1996). The preference for reduction could be caused by an increase of reduced cosubstrate (NADPH) and a lower intracellular $\mathrm{pH}$, due to anaerobic glycolysis in stress situations. At lower $\mathrm{pH}(6 \cdot 0)$ the reductase reaction is favoured over the dehydrogenase reaction ( $\mathrm{pH}$ 8.0) (Brown et al. 1993). A direct transcriptional regulation could also be a possibility, but would not explain the reduced oxidation and increased reductive activity of one enzyme. Therefore, this change in enzyme 
Table 3 Percentage conversion of cortisol (F) to cortisone (E) and vice versa in kidney and liver tissue slices with increasing concentrations of $\mathrm{ACTH}_{1-24}$ in vitro. Values are means \pm S.E.M $(n=3)$. Percentage conversion of controls was set at $100 \%$

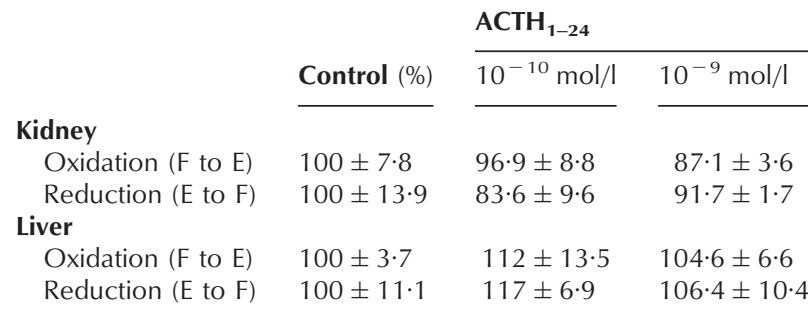

activity seems to correlate better with a shift of the equilibrium to the reductive side than with direct transcriptional changes.

We also observed marked oxidative activity in liver tissue slices. This can be explained by the activity of a third isoenzyme in guinea pig liver acting as a dehydrogenase (Quinkler et al. 1997). Since the oxidative activity was significantly decreased after in vivo ACTH treatment, an inhibition of this third $11 \beta-\mathrm{HSD}$ isoenzyme by ACTH treatment seems possible. This 11 $\beta-H S D$ isoenzyme could constitute a compensatory metabolic pathway for the poor cortisol metabolism by other enzymatic systems (e.g. ring $\mathrm{A}$ reduction) in the guinea pig liver (Abel et al. 1993).

Besides 11 $\beta$-HSD-2, the guinea pig kidney expresses $11 \beta-H S D-1$ similar to rat and mouse kidney (Quinkler et al. 1997, Pu \& Yang 2000). In vivo ACTH treatment increases renal reductive activity, possibly due to an activated $11 \beta-H S D-1$ activity. Although it is known that in the rat kidney $11 \beta-H S D-2$ is induced by GCs (Li et al. 1996), it seems as if the activation of type 1 isoenzyme would predominate in the guinea pig. It is also possible that the type 2 isoenzyme is inhibited by ACTH-induced steroids, e.g. progesterone and its metabolites, or by corticosterone (Diederich et al. 1996, Quinkler et al. 1999). Plasma cortisone concentration rises to over $300 \mathrm{nmol} / 1$ after ACTH treatment (Table 1) and cortisone has a lower corticosteroid-binding globulin affinity than cortisol. Therefore, end-product inhibition of 11ß-HSD-2 by cortisone, which was described previously (Rusvai \& Náray-Fejes-Tóth 1993, Albiston et al. 1994, Stewart et al. 1995), may also be an important reason for the decrease of renal $11 \beta-H S D-2$ activity in vivo. The physiological role of a decreased $11 \beta-H S D-2$ activity in response to stress is not clear. On the one hand, the body would need higher levels of oxidase activity in cells expressing the $\mathrm{MC}$ receptor to cope with increased cortisol levels and protect the MC receptor. But, on the other hand, even these cells may need a higher intracellular level of active GCs to respond adequately to stress. In addition, fluid retention is critical in stress, as we see it clinically in shock situations like septic or haemorrhagic shock, and traumata. Therefore an increased activation of the $\mathrm{MC}$ receptor would make sense.

A study in $11 \beta$-HSD-1 knock-out mice showed the importance of the 11 $\beta$-HSD-1 isoenzyme for GC action: a lack of this enzyme leads to a relative intracellular GC deficiency (Kotelevtsev et al. 1997). Since ACTH had no effect on the bidirectional enzyme activities when added in vitro to liver or kidney slices (Table 3 ), the activation of the $11 \beta-H S D-1$ after in vivo ACTH application is most likely mediated by cortisol itself or by other ACTH-induced steroids (Hammami \& Siiteri 1991, Walker et al. 1994, Jamieson et al. 1995, Voice et al. 1996). This is in accordance with the finding that $11 \beta$ HSD-1 activity is increased by dexamethasone in a rat hepatoma cell line (2S FAZA) (Voice et al. 1996), in primary culture of rat hepatocytes (Liu et al. 1996) and in rat liver in vivo (Jamieson et al. 1999). It was recently demonstrated that GC treatment caused a time- and dose-dependent increase in 11ß-HSD-1 mRNA and activity in primary cultures of human osteoblasts (Cooper et al. 2002).

Nevertheless, this activation of $11 \beta-H S D-1$ in stress situations could be an important regulatory principle in many organ systems. This enhanced 'GC tonus' is essential for stress adaptation, e.g. GC-induced increase of gluconeogenesis in the liver. Due to the increased conversion of inactive cortisone to active cortisol, the liver seems to be an important cortisol production site in stress situations, besides the adrenals.

This observation was underlined by the significantly elevated urinary $\mathrm{THF}+5 \alpha \mathrm{THF} / \mathrm{THE}$ ratio in the ACTH-treated group of guinea pig as a marker of $11 \beta-H S D-1$ activity (Fig. 2a). It has recently been proposed that the urinary ratio of THF $+5 \alpha \mathrm{THF} / \mathrm{THE}$ may also be an accurate marker for renal $11 \beta-H S D-2$ in humans (Ferrari et al. 2001). Due to different isoenzyme expression in the guinea pig kidney $(11 \beta-H S D-1$ in addition to $11 \beta-H S D-2)$ (Quinkler et al.1997, Pu \& Yang $2000)$, this cannot be easily transferred to the guinea pig. We rather interpret this ratio as a marker for hepatic 11ß-HSD-1 activity (Palermo et al. 1996, Quinkler et al. 2000). The urinary $5 \alpha \mathrm{THF} / \mathrm{THF}$ ratio, representing the balance between $5 \alpha$-reductases and $5 \beta$-reductase activities, did not change under ACTH treatment (Table 2). This implies that the increased THF $+5 \alpha \mathrm{THF} /$ THE ratio was not influenced by $5 \alpha$-reductases or $5 \beta$ reductase activities but represents an increased $11 \beta$ HSD-1 reductase activity. Surprisingly, the total amount of urinary tetrahydrometabolites was rather small compared with the human in relation to the cortisol concentration. This can be explained by the relatively poor cortisol metabolism to ring A-reduced metabolites in the guinea pig liver (Abel et al. 1993). Therefore these ratios need further assessment in this species. 
The urinary cortisol/cortisone ratio in the guinea pig is high (approximately 20), whereas in humans it is low (approximately $0 \cdot 5$ ). The urinary ratio cortisol/cortisone is an excellent marker for 11 $\beta$-HSD-2 in humans, because the human kidney expresses only $11 \beta-H S D-2$. But the ratio is a poor index for $11 \beta-H S D-2$ activity in the guinea pig, because both $11 \beta$-HSD enzymes are expressed in the kidney and contribute to the urinary cortisol/cortisone ratio. Therefore, it is difficult to compare human and guinea pig urinary cortisol/cortisone ratios. In situations of unchanged urinary cortisol/cortisone ratio in ACTHtreated animals, the increase in THF $+5 \alpha \mathrm{THF} / \mathrm{THE}$ ratio reflects an increase in 11 $\beta$-HSD-1 activity in the liver.

In summary, we have shown that in vivo ACTH treatment for 3 days increases the hepatic and renal $11 \beta$-reductase activity in the guinea pig. This activation is probably due to increased concentrations of cortisol or of other ACTH-dependent GCs rather than to ACTH itself. The stress-induced activation of the hormonally inactive cortisone to active cortisol in liver, kidney and other $11 \beta$-HSD-1-expressing organs seems to be an important local tissue regulatory mechanism besides the adrenal cortisol de novo synthesis. Up to now, this mechanism, which could also be present in other species such as the human, has not been noted to be involved in the elevation of cortisol by ACTH in humans.

\section{Acknowledgements}

This work was supported partly by grant DI 741/1-3 from the Deutsche Forschungsgemeinschaft (DFG). M Q is supported by a postdoctoral fellowship (QU142/1-1) of the DFG.

\section{References}

Abel SM, Back DJ, Maggs JL \& Park BK 1993 Cortisol metabolism in vitro. II Species difference. Journal of Steroid Biochemistry and Molecular Biology 45 445-453.

Albiston AL, Obeyesekere VR, Smith RE \& Krozowski ZS 1994 Cloning and tissue distribution of the human $11 \beta$-hydroxysteroid dehydrogenase type 2 enzyme. Molecular and Cellular Endocrinology 105 R11-R17.

Arriza JL, Weinberger C, Cerelli G, Glaser TM, Handelin BL, Housman DE \& Evans RM 1987 Cloning of human mineralocorticoid receptor complementary DNA: structural and functional kinship with the glucocorticoid receptor. Science 237 268-275.

Bach PH, Vickers AEM, Fisher R, Baumann A, Brittebo E, Carlile DJ, Koster HJ, Lake BG, Salmon F, Sawyer TW \& Skibinski G 1996 The use of tissue slices for pharmacotoxicology studies. The report and recommendations of ECVAM workshop 20. Alternatives to Laboratory Animals 24 893-923.

Best R, Nelson S \& Walker BR 1997 Dexamethasone and 11-dehydrodexamethasone as tools to investigate the isoenzymes of $11 \beta$-hydroxysteroid dehydrogenase in vitro and in vivo. Journal of Endocrinology 153 41-48.
Brown RW, Chapman KE, Edwards CR \& Seckl JR 1993 Human placental 11ß-hydroxysteroid dehydrogenase: evidence for and partial purification of a distinct NAD-dependent isoform. Endocrinology 132 2614-2621.

Cooper MS, Rabbitt EH, Goddard PE, Bartlett WA, Hewison M \& Stewart PM 2002 Osteoblastic 11ß-hydroxysteroid dehydrogenase type 1 activity increases with age and glucocorticoid exposure. Journal of Bone and Mineral Research 17 979-986.

Diederich S, Quinkler M, Miller K, Heilmann P, Schöneshöfer M \& Oelkers W 1996 Human kidney 11ß-hydroxysteroid dehydrogenase: regulation by adrenocorticotropin? European Journal of Endocrinology 134 301-307.

Diederich S, Hanke B, Oelkers W \& Bähr V 1997 Metabolism of dexamethasone in the human kidney: nicotinamide adenine dinucleotide-dependent 11-reduction. Journal of Clinical Endocrinology and Metabolism 82 1598-1602.

Edwards CR, Stewart PM, Burt D, Brett L, McIntyre MA, Sutanto WS, de Kloet ER \& Monder C 1988 Localisation of $11 \beta$-hydroxysteroid dehydrogenase - tissue specific protector of the mineralocorticoid receptor. Lancet 2 986-989.

Eisenschmid B, Heilmann P, Oelkers W, Rejaibi R \& Schöneshöfer M 1987 20-Dihydroisomers of cortisol and cortisone in human urine: excretion rates under different physiological conditions. Journal of Clinical Chemistry and Clinical Biochemistry 25 345-349.

Fenske M 1997 Role of cortisol in the ACTH-induced suppression of testicular steroidogenesis in guinea pigs. Journal of Endocrinology 154 407-414.

Ferrari P, Sansonnens A, Dick B \& Frey FJ 2001 In vivo 11ß-HSD-2 activity: variability, salt-sensitivity, and effect of licorice. Hypertension 38 1330-1336.

Fujieda K, Goff AK, Pugeat M \& Strott CA 1982 Regulation of the pituitary-adrenal axis and corticosteroid-binding globulin-cortisol interaction in the guinea pig. Endocrinology 111 1944-1950.

Funder JW, Pearce PT, Smith R \& Smith AI 1988 Mineralocorticoid action: target tissue specificity is enzyme, not receptor, mediated. Science 242 583-585.

Hammami MM \& Siiteri PK 1991 Regulation of 11ß-hydroxysteroid dehydrogenase activity in human skin fibroblasts: enzymatic modulation of glucocorticoid action. Journal of Clinical Endocrinology and Metabolism 73 326-334.

Hodgson AJ \& Funder JW 1978 Glucocorticoid receptors in the guinea pig. American Journal of Physiology 235 R115-R120.

Hundertmark S, Bühler H, Ragosch V, Dinkelborg L, Arabin B \& Weitzel HK 1995 Correlation of surfactant phosphatidylcholine synthesis and 11ß-hydroxysteroid dehydrogenase in the fetal lung. Endocrinology 136 2573-2578.

Jamieson PM, Chapman KE, Edwards CRW \& Seckl JR 1995 $11 \beta$-Hydroxysteroid dehydrogenase is an exclusive $11 \beta$-reductase in primary cultures of rat hepatocytes: effect of physiochemical and hormonal manipulations. Endocrinology 136 4754-4761.

Jamieson PM, Chapman KE \& Seckl JR 1999 Tissue- and temporal-specific regulation of $11 \beta$-hydroxysteroid dehydrogenase type 1 by glucocorticoids in vivo. Journal of Steroid Biochemistry and Molecular Biology 68 245-250.

Jamieson PM, Walker BR, Chapman KE, Andrews R, Rossiter S \& Seckl JR $200011 \beta$-Hydroxysteroid dehydrogenase type 1 is a predominant $11 \beta$-reductase in the intact perfused rat liver. Journal of Endocrinology 165 685-692.

Keightley MC \& Fuller PJ 1996 Anomalies in the endocrine axes of the guinea pig: relevance to human physiology and disease. Endocrine Reviews 17 30-44.

Keightley MC, Funder JW \& Fuller PJ 1991 Molecular cloning and sequencing of a guinea-pig pro-opiomelanocortin cDNA. Molecular and Cellular Endocrinology 82 89-98.

Kotelevtsev Y, Holmes MC, Burchell A, Houston PM, Schmoll D, Jamieson P, Best R, Brown R, Edwards CR, Seckl JR \& Mullins JJ 199711 beta-hydroxysteroid dehydrogenase type 1 knockout 
mice show attenuated glucocorticoid-inducible responses and resist hyperglycemia on obesity or stress. PNAS 94 14924-14929.

Kraft N, Hodgson AJ \& Funder JW 1979 Glucocorticoid receptor and effector mechanisms: a comparison of the corticosensitive mouse with the corticoresistant guinea pig. Endocrinology 104 344-349.

Li KXZ, Smith RE, Ferrari P, Funder JW \& Krozowski ZS 1996 Rat $11 \beta$-hydroxysteroid dehydrogenase type 2 enzyme is expressed at low levels in the placenta and is modulated by adrenal steroids in the kidney. Molecular and Cellular Endocrinology 120 67-75.

Li KXZ, Obeyesekere VR, Krozowski ZS \& Ferrari P 1997 Oxoreductase and dehydrogenase activities of the human and rat $11 \beta$-hydroxysteroid dehydrogenase type 2 enzyme. Endocrinology 138 2948-2952.

Liu YJ, Nakagawa Y, Nasuda K, Saegusa H \& Igarashi Y 1996 Effect of growth hormone, insulin and dexamethasone on 11ß-hydroxysteroid dehydrogenase activity on a primary culture of rat hepatocytes. Life Sciences 59 227-234.

Martin MJ, McClelland AE \& Funder JW 1980 The pituitary-adrenal axis in the guinea pig: studies on ACTH secretion. Clinical and Experimental Pharmacology and Physiology 7 46-47.

Maser E, Richter E \& Friebertshäuser J 1996 The identification of $11 \beta$-hydroxysteroid dehydrogenase as carbonyl reductase of the tobacco-specific nitrosamine 4-(methylnitrosamino)-1-(3-pyridyl)1-butanone. European Journal of Biochemistry 238 484-489.

Maser-Gluth C, Reincke M, Allolio B \& Schulze E 2000 Metabolism of glucocorticoids and mineralocorticoids in patients with adrenal incidentalomas. European Journal of Clinical Investigation 30 (Suppl 3) 83-86.

Michael AE \& Cooke BA 1994 A working hypothesis for the regulation of steroidogenesis and germ cell development in the gonads by glucocorticoids and $11 \beta$-hydroxysteroid dehydrogenase (11ß-HSD). Molecular and Cellular Endocrinology 100 55-63.

Myles K \& Funder JW 1994 Type I (mineralocorticoid) receptors in the guinea pig. American Journal of Physiology 267 E268-E272.

Nwe KHH, Hamid A, Morat PB \& Khalid BAK 2000 Differential regulation of the oxidative $11 \beta$-hydroxysteroid dehydrogenase activity in testis and liver. Steroids $\mathbf{6 5} 40-45$.

Oelkers W, Buchen S, Diederich S, Krain J, Muhme S \& Schöneshöfer M 1994 Impaired renal 11ß-oxidation of 9 alphafluorocortisol: an explanation for its mineralocorticoid potency. Journal of Clinical Endocrinology and Metabolism 78 928-932.

Palermo M, Shackleton CHL, Mantero F \& Stewart PM 1996 Urinary free cortisone and the assessment of $11 \beta$-hydroxysteroid dehydrogenase activity in man. Clinical Endocrinology 45 605-611.

Provencher PH, Tremblay Y, Caron S \& Belanger A 1992 Effect of chronic ACTH treatment on guinea-pig adrenal steroidogenesis steroid plasma levels, steroid adrenal levels, activity of steroidogenic enzymes and their steady-state messenger RNA levels. Journal of Steroid Biochemistry and Molecular Biology 41 69-78.

$\mathrm{Pu}$ X \& Yang K 2000 Guinea pig 11 $\beta$-hydroxysteroid dehydrogenase type 1: primary structure and catalytic properties. Steroids $\mathbf{6 5}$ 148-156.

Quinkler M, Kosmale B, Bähr V, Oelkers W \& Diederich S 1997 Evidence for isoforms of $11 \beta$-hydroxysteroid dehydrogenase in the liver and kidney of the guinea pig. Journal of Endocrinology 153 291-298.

Quinkler M, Johanssen S, Grossmann C, Bähr V, Muller M, Oelkers W \& Diederich S 1999 Progesterone metabolism in the human kidney and inhibition of $11 \beta$-hydroxysteroid dehydrogenase type 2 by progesterone and its metabolites. Journal of Clinical Endocrinology and Metabolism 84 4165-4171.
Quinkler M, Oelkers W \& Diederich S 2000. In vivo measurement of renal 11ß-hydroxysteroid dehydrogenase type 2 activity. Journal of Clinical Endocrinology and Metabolism 85 4921-4922.

Quinkler M, Oelkers W \& Diederich S 2001 Clinical implications of glucocorticoid metabolism by $11 \beta$-hydroxysteroid dehydrogenases in target tissues. European Journal of Endocrinology 144 87-97.

Rusvai E \& Náray-Fejes-Tóth A 1993 A new isoform of $11 \beta$-hydroxysteroid dehydrogenase in aldosterone target cells. Journal of Biological Chemistry 268 10717-10720.

Shinzawa K, Kominami S \& Takemori S 1985 Studies on cytochrome P-450 (P-450 17 alpha,lyase) from guinea pig adrenal microsomes. Dual function of a single enzyme and effect of cytochrome b5. Biochimica et Biophysica Acta 833 151-160.

Stewart PM 1996 11ß-Hydroxysteroid dehydrogenase: implications for clinical medicine. Clinical Endocrinology 44 493-499.

Stewart PM \& Krozowski Z 1999 11ß-Hydroxysteroid dehydrogenase. Vitamins and Hormones 57 249-324.

Stewart PM \& Tomlinson JW 2002 Cortisol, 11 $\beta$-hydroxysteroid dehydrogenase type 1 and central obesity. Trends in Endocrinology and Metabolism 13 94-96.

Stewart PM, Whorwood CB \& Mason JI 1995 Type 2 11ßhydroxysteroid dehydrogenase in foetal and adult life. Journal of Steroid Biochemistry and Molecular Biology 55 465-471.

Tannin GM, Agarwal AK, Monder C, New MI \& White PC 1991 The human gene for 11 $\beta$-hydroxysteroid dehydrogenase. Structure, tissue distribution, and chromosomal localization. Journal of Biological Chemistry 266 16653-16658.

Tetsuka M, Thomas FJ, Thomas MJ, Anderson RA, Mason JI \& Hillier SG 1997 Differential expression of messenger ribonucleic acids encoding 11 $\beta$-hydroxysteroid dehydrogenase types 1 and 2 in human granulosa cells. Journal of Clinical Endocrinology and Metabolism 82 2006-2009.

Tomlinson JW, Moore J, Cooper MS, Bujalska I, Shahmanesh M, Burt C, Strain A, Hewison M \& Stewart PM 2001 Regulation of expression of $11 \beta$-hydroxysteroid dehydrogenase type 1 in adipose tissue: tissue-specific induction by cytokines. Endocrinology 142 1982-1989.

Ulick S, Wang JZ, Blumenfeld JD \& Pickering TG 1992 Cortisol inactivation overload: a mechanism of mineralocorticoid hypertension in the ectopic adrenocorticotropin syndrome. Journal of Clinical Endocrinology and Metabolism 74 963-967.

Voice MW, Seckl JR, Edwards CRW \& Chapman KE 1996 $11 \beta$-Hydroxysteroid dehydrogenase type 1 expression in 2S FAZA hepatoma cells is hormonally regulated: a model system for the study of hepatic glucocorticoid metabolism. Biochemical Journal 317 621-625.

Walker BR, Campbell JC, Fraser R, Stewart PM \& Edwards CR 1992 Mineralocorticoid excess and inhibition of $11 \beta$-hydroxysteroid dehydrogenase in patients with ectopic ACTH syndrome. Clinical Endocrinology 37 483-492.

Walker BR, Williams BC \& Edwards CRW 1994 Regulation of $11 \beta$-hydroxysteroid dehydrogenase activity by the hypothalamic-pituitary-adrenal axis in the rat. Journal of Endocrinology 141 467-472.

Received 10 October 2002

Accepted 23 October 2002 